\title{
Locked-up and in Limbo: Living Stateless in my Hometown Jail Deepan Budlakoti
}

Twas born and raised in Canada, and have lived my entire life in Ottawa, Ontario. Prior to 2009, I held a Canadian passport, a birth certificate, an Ontario health card and driver's license. I was born at Ottawa's Grace hospital and maintained birthright citizenship in Canada from that point up until my incarceration in 2009. At that time, I was informed that the Canadian government had revoked my citizenship while I awaited trial. This meant that my status in Canada changed from 'citizen' to 'permanent resident' without any opportunity for due process.

The Canada Border Service Agency (CBSA) argued that my passport was issued in error, as it was alleged that my parents had been employed as diplomats to the Indian High Commission at the time of my birth in 1989. I disputed this claim because my parents left their positions at the Indian High Commission months before my birth, a fact that has been well supported by affidavits from the Indian High Commission and a local employer who confirmed that my parents were employed by a Canadian business when I was born. Upon the revocation of my citizenship, my re-classification as a permanent resident meant that a deportation order would be issued on the grounds of criminal inadmissibility. In Canada, when someone with permanent residency is sentenced to a period of more than six months, they can be deported on the grounds of 'criminality' or 'serious criminality' following the completion of their custodial sentence (Benslimane and Moffette, 2020). While I await deportation on these grounds, there is nowhere for me to be deported to as I do not have citizenship or resident status in any other country.

My lack of resident status in Canada or elsewhere in the world has left me 'stateless'. Being stateless means that I have no status in a country, no recognition of rights in general and I do not have citizenship anywhere (Stasiulis, 2017). I do not have the same opportunities as everyone else for work and education so while waiting to secure these things by acquiring work or study permits I was in limbo with extremely limited options, and faced an increased risk of being incarcerated due to low socioeconomic opportunities. This can create a loss of identity stemming from the fact that people revoked on the grounds of criminal inadmissibility are not recognized as citizens with the same rights and protections that they would have had otherwise. The concept of 'not having' is key; the fact that I no longer 
possessed the legal entitlements I had held since birth meant that many limitations were put on my life in terms of school, paying rent, getting a job, obtaining work permits and living a normal life. This extraneous pressure can exacerbate underlying mental health issues and create a sense of grief for the loss of one's former life and anxiety concerning an uncertain future.

Following the completion of my first federal sentence, I was gated on immigration grounds. While leaving the penitentiary, I had to be stripsearched and transferred to Toronto West Detention Centre, rather than sent home to my family and community who were awaiting my return. I had done my time and was supposed to be free, but instead I found myself triplebunked with two men, unable to reach loved ones and without any real privacy whatsoever for an indefinite amount of time. Rather than a door, our cell had bars so I had to use my bed sheets to cover the grill in order to have any privacy from the view of others while using the washroom.

My time at Toronto West Detention Centre protracted the punishment that I experienced throughout my previous federal sentence. However, I was not charged with anything, but rather waiting for a country I had never lived in to recognize me as a citizen, which they have still to this day yet to do. No one should have to live in the conditions I endured during my time in immigration detention. The indefinite nature of my detention there inflicted another degree of punishment, introducing me to the fearful uncertainty I would be consumed by for the next several years.

Eventually, after many unsuccessful detention reviews, I was finally released on immigration bail. My immigration conditions were quite similar to my parole conditions: I was required to sign in with immigration on a regular basis, give up my liberties, and provide everything CBSA asked me to for fear of breaching my conditions and being detained indefinitely yet again. While navigating these stringent conditions, I lived in constant fear that at any given time CBSA could come and grab me. I found myself constantly looking over my shoulder, unsure of whether I was being monitored or if CBSA was coming to check on me.

Due of these conditions, I felt as if I could not move on with my life and I was left in limbo. This uncertainty put a strain on my personal relationships and reduced my access to the support system I desperately needed to keep my life going in the right direction. Knowing I could be pulled from my loved ones and detained indefinitely is incredibly stressful. It feels akin to being on parole for life in the sense that, for the rest of my life, I will 
spend my time out of custody on stringent immigration bail conditions that are quite akin to parole conditions. If I violate them, I will be indefinitely detained. The threat of being detained indefinitely for an administrative breach of conditions had serious impacts on my mental health and wellbeing. Immigration can show up to my door at any time even just to check up on me and I dreaded having to explain the appearance of several armed CBSA officers at my home to neighbours and friends. Being stateless stripped me of my identity and left me isolated, stuck in limbo without any support or social assistance.

Although living under these conditions was incredibly stressful, I used my time on immigration bail to advocate for my rights and filed a United Nations Human Rights application and a charter application in federal court. In April 2018, the UN Human Rights Commission came to a decision on my status and ruled that I am a Canadian Citizen who is entitled to the rights and protections allotted to all Canadians. However, the Canadian government has yet to rectify this and I continue to be without status in Canada or anywhere else in the world.

The fact that I could not have a Canadian passport, identification or even a bank account while dealing with PTSD and anxiety on a daily basis was a revolving door. When I became stateless, I did not any receive help with my reintegration back into society after spending time in the penitentiary and immigration detention. The Canadian government stripped me of my identity and took away my access to universal health care at a time when I was in dire need of it. Following this period on immigration bail, I found myself back in custody on new charges and I remain incarcerated at the Ottawa-Carleton Detention Centre to this day awaiting trial. People look at me differently here because of my citizenship status. I live in a hallway that is 7.5 feet by 113 feet. I live in a cell with no window or fresh air. I sit on the floor and eat in front of an open toilet; it is as if I am living in a washroom. Dignity and respect are nonexistent, lockdowns are a regular occurrence and my liberties have been taken away.

Despite the Canadian government's claim that my parents should have applied for citizenship on my behalf upon their decision to settle in Canada, I was a crown ward from the age of 13 and the onus was on the Ontario government to apply for such status on my behalf during the five years I was in CAS custody. I ran away from home at nine years old and ended up in group homes at a young age. I had to deal with tremendous personal 
issues such as being sexually assaulted when I was a child in group home care. As a result, I ran away from group homes, slept on a bench in the park and at different friends' houses. The Ontario government failed to keep me safe when I was under their care as a child, while the Canadian government continues to demonstrate a similar indifference to my humanity as an adult in their refusal to acknowledge my citizenship in the country I was born.

Despite its failure to abide by the UN decision upholding my citizenship, the Canadian government acted differently in another case. When Alex and Timothy Vavilov, the sons of Russian spies born in Canada, fought for their own Canadian citizenship, the Supreme Court upheld their status in Canada. Following the decision their lawyer stated, "[the] profound ordeal in the past decade has shown us that wrongful denial of the right of citizenship by birth is too high of a cost for a person to bear". After dealing with my own loss of status over the past decade, I agree that the personal cost of such revocation is incredibly difficult to bear.

While there are key parallels between my immigration case and that of the Vavilov brothers, there are two differences that I feel differentiate our experiences: (1) the Vavilov brothers are white, whereas I am a person of colour in this country; and (2) I am facing criminal charges, while they were not. Living as a person of colour who has been criminalized, I feel that the Canadian government treats me as more disposable than these young white men who were granted the birthright citizenship that has been stripped from me. It has become clear over the years that the Canadian government does not care about me as I continue to be neglected and dehumanized in state custody, just as I was in childhood during my time as a crown ward.

In refusing to allow me any citizenship status in this country, while knowing I am unable to obtain it elsewhere, the Canadian government considers me to be someone who could be detained indefinitely without due process. This indefinite detention is not the default in other countries. For example, the United States places time limits on the detention of people with precarious immigration status pending removal. Through this experience of indefinite detention, I am being punished not only for the allegations I have faced, but also for a loss of status that was entirely beyond my own control. While the Canadian government vied for a spot on the UN security council, which it ultimately failed to secure, it had not yet adopted the UNHRC decision that found that Canada's treatment of me is a violation of a number of my entitlements under the international covenant on civil and 
political rights. The committee ruled that Canada is my home country and that it violated article 12(4) of the ICCPR, which states that those born in a country have an entitlement to birthright citizenship. Furthermore, if I was to be deported to India, my right not to be arbitrarily deprived entry to my own country would be violated. The committee also found that my removal to India would violate my right to non-interference with my family's life under article 17 and 23(1) of the ICCPR.

The Canadian government needs to abide by the ruling of the United Nations Human Rights Commission and restore my status in this country so that I can move on with my life and contribute to society to my fullest potential. I am not disposable. I am a valued member of the community and country I was born and raised in. I contribute to my community. The Canadian government must recognize this truth and treat me accordingly as the denial of my rights and deprivation of basic necessities opens the door to the dehumanizing, degrading, and undignified treatment of others.

\title{
REFERENCES
}

Benslimane, Souheil and David Moffette (2019) "The Double Punishment of Criminal

Inadmissibility for Immigrants", Journal of Prisoners on Prisons, 28(1): 44-65. Stasiulis, Daiva (2017) "The Extraordinary Statelessness of Deepan Budlakoti: The

Erosion of Canadian Citizenship through Citizenship Deprivation", Studies in Social Justice, 11(1): 1-26.

\section{ABOUT THE AUTHOR}

Deepan Budlakoti is incarcerated at Ottawa-Carleton Detention Centre. He is an advocate for the human rights of prisoners and people with precarious immigration status. He can be reached by mail at:

\author{
Deepan Budlakoti \\ Ottawa-Carleton Detention Centre \\ 2244 Innes Road \\ Gloucester, Ontario, Canada \\ K1B 4C4
}

